\title{
Phytochemistry and biological activities of Opuntia seed oils: Opuntia dillenii (Ker Gawl.) Haw. and Opuntia ficus-indica (L.) Mill. A review
}

\author{
MOHAMED BOUHRIM $^{1 \oplus}$, SALIHA BOUKNANA ${ }^{1 \oplus}$, HAYAT OUASSOU $^{1 \oplus}$, SALIMA BOUTAHIRI $^{2 \oplus}$, \\ NOUR ELHOUDA DAOUDI ${ }^{1 \oplus}$ MOHAMED BNOUHAM $^{1 * \odot}$
}

\author{
${ }^{1}$ Laboratory of Bioresources, Biotechnology, Ethnopharmacology and Health \\ Mohammed First University \\ Faculty of Sciences \\ B.P. 717 60000, Oujda, Morocco \\ ${ }^{2}$ Laboratory of Innovative Materials and Biotechnology of Natural Resources \\ Faculty of Sciences \\ Moulay Ismail University, \\ B.P. 11201 Zitoune, Meknes, Morocco
}

*corresponding author: phone: +212 6676 27496; fax: +212 5365 00603; e-mail: mbnouham@yahoo.fr

\section{Summary}

Opuntia species belong to semi-arid and arid regions of Mexico and the United States. O. ficus-indica and O. dillenii are commonly used in alternative medicine to treat various diseases. Up to date, several scientific works have been carried out on the different parts of these plants. However, over the last few years, studies have been focusing on the oil obtained from the fruit seeds of these species. For this reason, this study aims to draw the attention of researchers toward the phytochemical and the pharmacological effects of these two Opuntia oils, which would help set up other scientific projects that promote these products. Phytochemical studies have shown that these oils are rich in biologically active molecules, such as unsaturated fatty acids and phytosterols (mainly linoleic acid and $\beta$-sitosterol), as well as vitamin E, which is represented only by the $\gamma$-tocopherol. Besides, these oils are rich in polyphenols that protect them from photo-oxidation. Moreover, several studies have shown their antioxidant, anti-diabetic, antibacterial, antifungal, anti-inflammatory, hepatoprotective, and gastroprotective activities, as well as their hypolipidemic properties. The beneficial effects of these oils include also their ability to block the weight loss, and what makes them more interesting is their safety, according to the literature.

Key words: Opuntia ficus-indica, Opuntia dillenii, seed oil, phytochemistry, biological effect

Słowa kluczowe: Opuntia ficus-indica, Opuntia dillenii, olej z nasion, fitochemia, działanie biologiczne 


\section{INTRODUCTION}

Opuntia is a plant species belonging to the Cactaceae family. It is native to semi-arid and arid regions of Mexico and the southern United States [1]. This genus was introduced to Europe and North Africa in the $16^{\text {th }}$ century [2], and it is currently found everywhere in the world. Moreover, among the Cactaceae family, O. dillenii and O. ficus-indica are the most frequently used species in the traditional medicine of many countries to treat several pathologies [3-6]. However, little interest has been given to the use of the fruit seeds because the body is unable to digest them and therefore to benefit from their constitutions. Several scientific studies have been interested in studying the different vegetative parts (pulp, seed, peel, and cladode) of these two species to assess or confirm their beneficial biological effects on various diseases $[7,8]$. Over the last few years, researchers have been interested in studying the seed oils of these two Opuntia species and have found that they are rich in very active molecules $[9,10]$. Other studies have shown several biological effects of these oils.

The bibliographic research was focused on the phytochemical and biological studies of O. ficus-indica and $O$. dillenii seed oils. The phytochemical profile of these two Opuntia oils has shown an abundance of unsaturated fatty acids, sterols, tocopherols and polyphenols. Moreover, their biological potentials cover the antioxidant, antidiabetic, anti-inflammatory, antibacterial, antifungal, hypolipidemic, hepatoprotective and gastroprotective properties, as well as the inhibition of weight loss.

This review provides a detailed overview of the seed oils obtained from O. dillenii and O. ficus-indi$c a$ and covers phytochemical, pharmacological and toxicological studies.

\section{METHODOLOGY}

In this article, a comprehensive literature search has been conducted to provide a thorough overview of the seed oils of $O$. ficus-indica and O. dillenii. Our literature search was done using Google Scholar search engine and via PubMed, Scopus, Science Direct databases, using the following keywords: "O. ficus-indica", "O. dillenii", "seed oil", "phytochemistry" and "biological effect". Reference lists of the papers that were retrieved were also examined to identify further papers. This bibliographic search was focused on all the articles published in 4 years (2018-2021).

\section{PHYTOCHEMISTRY OF OPUNTIA OILS}

The seeds of Opuntia arouse a lot of interest over the last few years. Their constituents were characterized in multiple studies and their nutritional values were evaluated. Besides, studies were focused on the oil contained in the seeds of Opuntia of which the yield is variable despite the geographical and climatic proximity between countries. In general, there are several techniques for extracting the high added value products present in plants. These techniques can be conventional (used for a long time) or new (developed recently) [11]. The vegetable oil from Opuntia seeds is mainly obtained by solvent extraction. Other methods, like cold pressing and supercritical carbon dioxide extraction, are used less frequently. The yield is generally low and varies from one extraction technique to another. The difference in the oil content of cactus seeds from different locations can be explained by the variability in geographic, climatic and environmental conditions. Other reasons, such as analytical conditions, may also affect this content [12]. The seed oil yield of Opuntia (7 to 15\%) is much lower than those reported for other well-known seed oils such as argan kernels (50\%), unroasted argan (28.49\%), sesame seed (54\%), black seed (34\%), sunflower (44\%), soybean (19\%) and olives (20\%) [13-16]. Moreover, the seed oil yield of these two Opuntia species (O.ficus-indica and $O$. dillenii) is high when compared to others, such as the Xoconostle seeds oil from Mexico (2.45 and 3.52\%) [17]. These oils belong to the category of "polyunsaturated" fatty acids like the majority of vegetable oils. According to all the studies carried out on the chemical composition of these oils, they are composed of a high amount of fatty acids, in particular polyunsaturated fatty acids, mainly linoleic acid and oleic acid. The latter ones have the property to reduce the risk of developing inflammatory, autoimmune and cardiovascular diseases. These oils are also rich in unsaponifiable compounds, in general $\beta$-sitosterol (which is the base of the active ingredients and that can be found in medicinal plants) [18] and $\gamma$-tocopherol (an antioxidant nutrient that plays an important role in neutralizing free radicals generated by the normal cell activity and by various stressors). Tocopherols are antioxidant molecules that prevent the initiation of lipid peroxidation. They have also shown the ability to neutralize lipid peroxide radicals [19]. Among all these phytochemical studies, there are the ones that were interested in the quantification and identification of the polyphenols of $O$. dillenii seed oil. It was confirmed that these molecules exhibit antioxidant, anti-cancer, anti-inflammatory 
and antiviral activities. These activities are attributed to the ability of these compounds to reduce free radicals, but also to their affinity for a wide variety of proteins, including certain enzymes (angiotensin II, $\beta$-glucuronidase, UDP-glucuronosyltransferase, catechol-O-methyl transferase, sulfotransferases) and receptors (estrogenic receptors) [20]. Also, the used technique of extraction influences the quantity and quality of the extracted polyphenols [11]. In a study realized on $O$. dillenii oil, they showed that the technique used to extract the oil from the seeds of this plant influences the yield, the diversity of phenolic compounds and the biological activity of this oil. The oil extracted with $\mathrm{SC}-\mathrm{CO}_{2}$ was highly enriched with polyphenols than the one extracted with hexane. The polyphenol profiles showed that the $\mathrm{SC}-\mathrm{CO}_{2}$ process extracts more compounds ( 45 compounds) than hexane (11 compounds). In addition, the antioxidant and antimicrobial activities of SC- $\mathrm{CO}_{2}$ extract was higher [10].

\section{Fatty acids}

The chemical composition study of the seed oils obtained from O. ficus-indica and O. dillenii has shown that these two oils belong to "polyunsaturated" oils [21]. Linoleic acid remains the predominant fatty acid in these seed oils, despite the origin of the plant (Morocco, Algeria, Tunisia, Turkey, Germany, Mexico and China), followed by palmitic acid and oleic acid $[9,14,22-28]$. The chemical composition of these Opuntia oils is similar to those of other Opuntia species like O. elatior [29]. In general, this major fatty acid is high in $O$. dillenii oil in comparison with O. ficus-indica oil. Moreover, O. ficus-indica seed oil from the region of Ain el Rahma in Algeria contains the greatest linoleic acid content in comparison with other regions [9]. However, the absence of oleic acid has been noticed in $O$. dillenii seed oils from Morocco and China $[9,30]$. Also, other fatty acids were determined in small amounts in these oils: palmitic, myristic, stearic, palmitoleic, elaidic, vaccenic, arachidic, linoleic, oleic, linolenic, behenic, cetoleic, and lignoceric (fig. 1) [31]. The difference in the quality and quantity of fatty acids in O. dillenii and O. ficus-indica oils is generally linked to the climate and the geographical area that these two plants come from [32]. Moreover, the fatty acid composition of cactus grown in different places is significantly different. It is well known that this composition is strongly influenced by the climatic factors and the type of soil in which they have grown [33]. Likewise, genetic factors may be involved as well. In a study performed in Morocco, O. dillenii oil (80.38) is richer in polyunsaturated fatty acids than O. ficus-indica oil (69.83) [9]. These results are in agreement with those published by Tlili $e t$ al. [31] where they found that $O$. ficus-indica oil contains $56.6 \%$ of linoleic acid, $20.19 \%$ of oleic acid, $12.24 \%$ of palmitic acid and $3.69 \%$ of stearic acid. On the contrary, Yuan-Gang et al. [30] reported that linolenic acid represents the main constituent of fatty acids (66.56\%) in the oil of total lipids O. dillenii, followed by palmitic acid (19.78\%), stearic acid (9.01\%) and linoleic acid (2.65\%). The difference observed could be due to the degree of maturity of the fruit. Indeed, these authors suggested that there was an increase in the content of saturated fatty acids towards the end of the fruit ripening.

\section{Sterols}

All the phytochemical studies that have been performed on Opuntia seed oils to determine their phytosterols composition have shown that only seed oils from Morocco, Tunisia, and Germany are rich in sterols, with $\beta$-sitosterol being the most dominant. O. ficus-indica seed oil is the richest in sterol content, in comparison to oils from other Opuntia species $[9,14,24,28,34]$. Indeed, this phytosterol is also found in other vegetable oils, such as soybean, sunflower and olive oils $[16,35]$. Concerning the sterol diversity, seed oils from Morocco (Sidi Ifni) and Tunisia (Zelféne, Sbeïtla and Kairouan) are the richest in sterol types (campesterol, $\Delta 5$-avenasterol, stigmasterol, $\Delta 7$-avenasterol, $\Delta 7$-stigmasterol and cholesterol) (fig. 2) [14, 24].

\section{Vitamin E}

The high content of total tocopherols is the specificity of cactus seed oils $[12,16,28]$. On the one hand, studies have shown that $O$. ficus-indica oil is very rich in tocopherols, and $\gamma$-tocopherol is the most dominant in this oil $[9,12,28,34,36,37]$. On the other hand, these constituents were absent or present in small quantities in O. dillenii seed oil. Oils from the regions of Berlin (Germany) and Sidi Ifni (Morocco) have the highest $\gamma$-tocopherol content in comparison with Opuntia seed oils from other regions in Morocco (Oujda) and Tunisia $[9,27]$. Also, seed oils from these two countries are characterized by the presence of other tocopherol types, generally $\alpha$-tocopherol, $\beta$-tocopherol, $\beta$-carotene and vitamin $\mathrm{K}_{1}$ (fig. 3) $[14,28]$. 


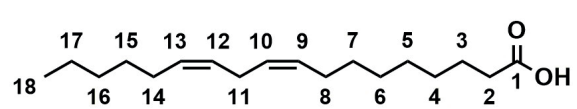

Linoleic acid

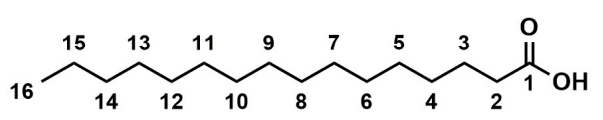

Palmitic acid

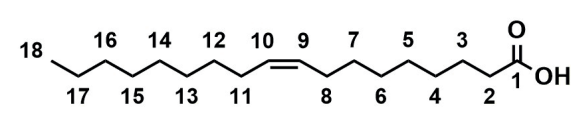

Oleic acid

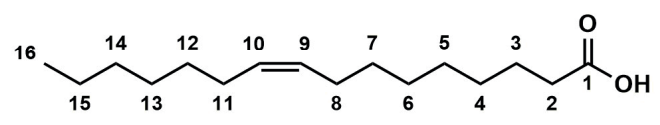

Palmitoleic acid

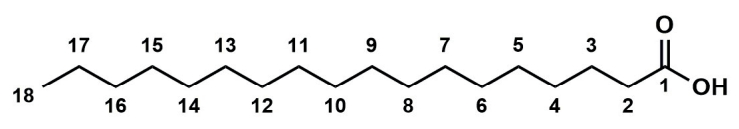

Stearic acid

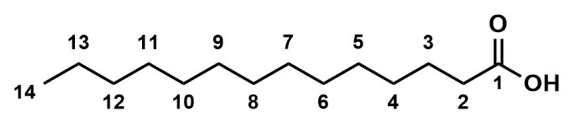

Myristic acid<smiles>CCCCCCCCC=CCCCCCCCCC(=O)O</smiles>

Elaidic acid

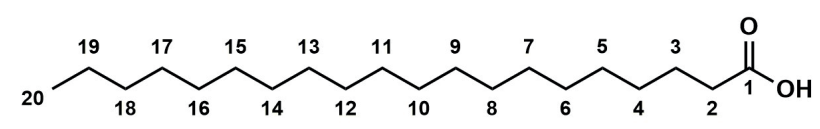<smiles>CCCCCCC=CCCCCCCCCCCC(=O)O</smiles>

Arachidic acid

Vaccenic acid

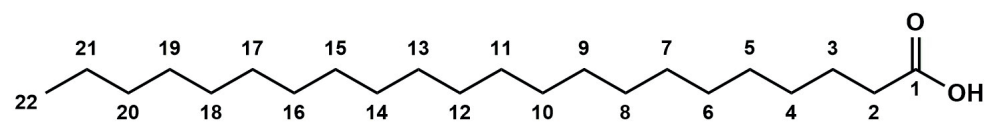

Behenic acid<smiles>CCCCCCCCCC=CC=CCCCCCCCCCC(=O)O</smiles>

Cetoleic acid

(Z)-docos-11-enoic acid

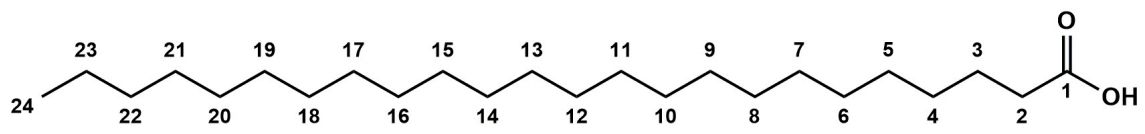

Lignoceric acid<smiles>CPC#CC=CC=CC=CCCCCCCCC(=O)O</smiles>

Linolenic acid

Figure 1.

Structural formulas of fatty acids present in Opuntia oil 

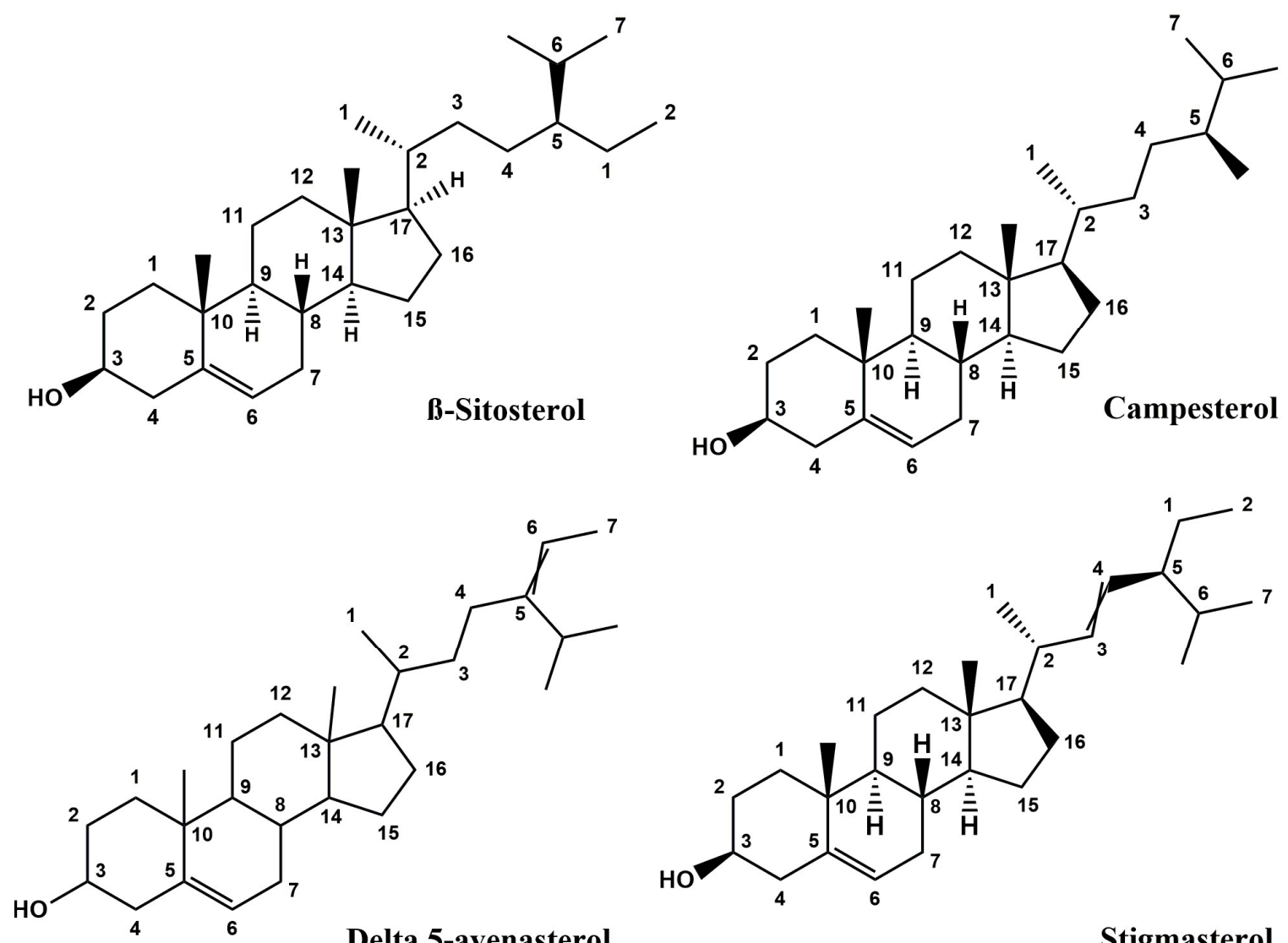

Delta 5-avenasterol

Stigmasterol
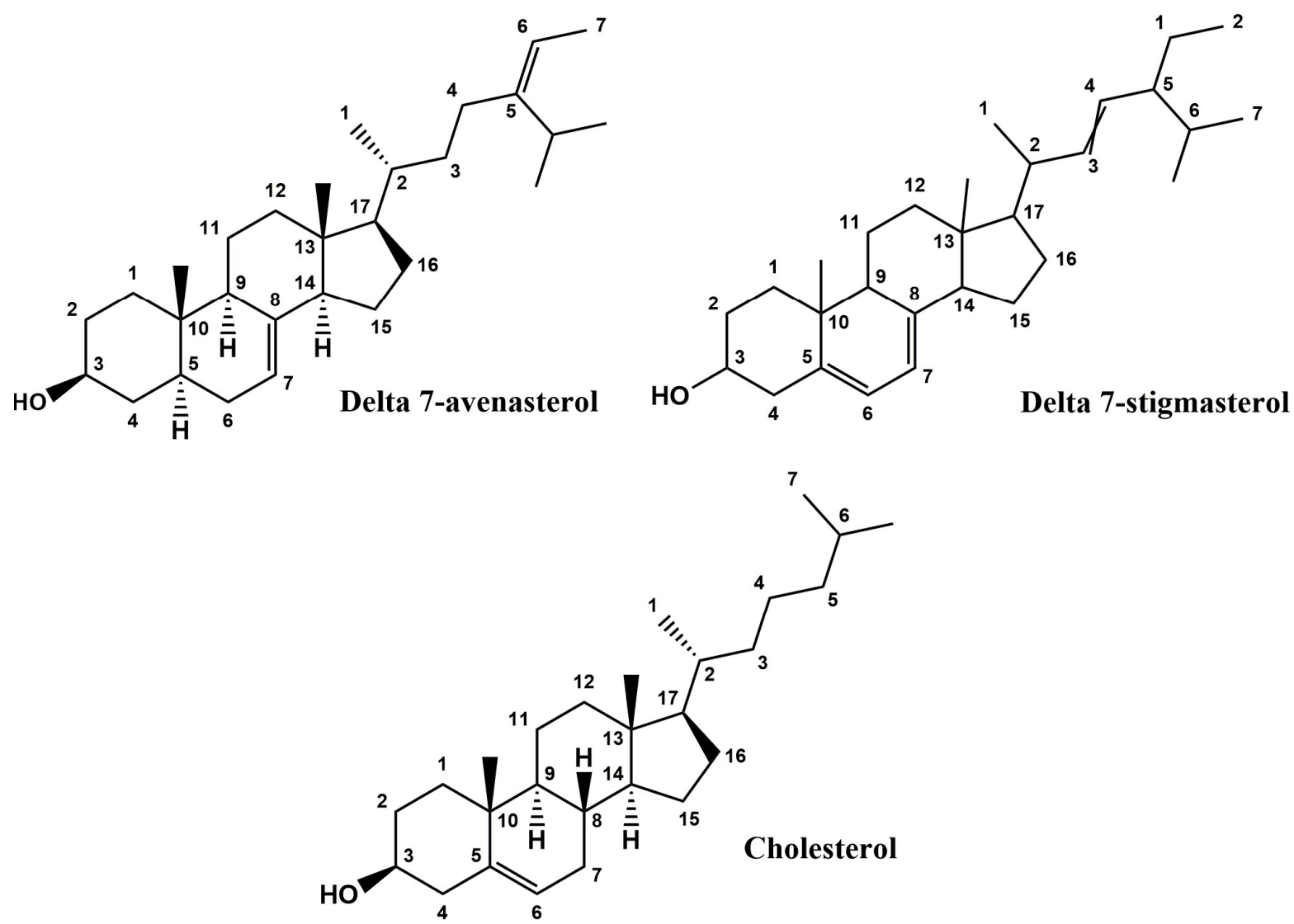

Figure 2.

Structural formulas of phytosterols present in Opuntia oil 

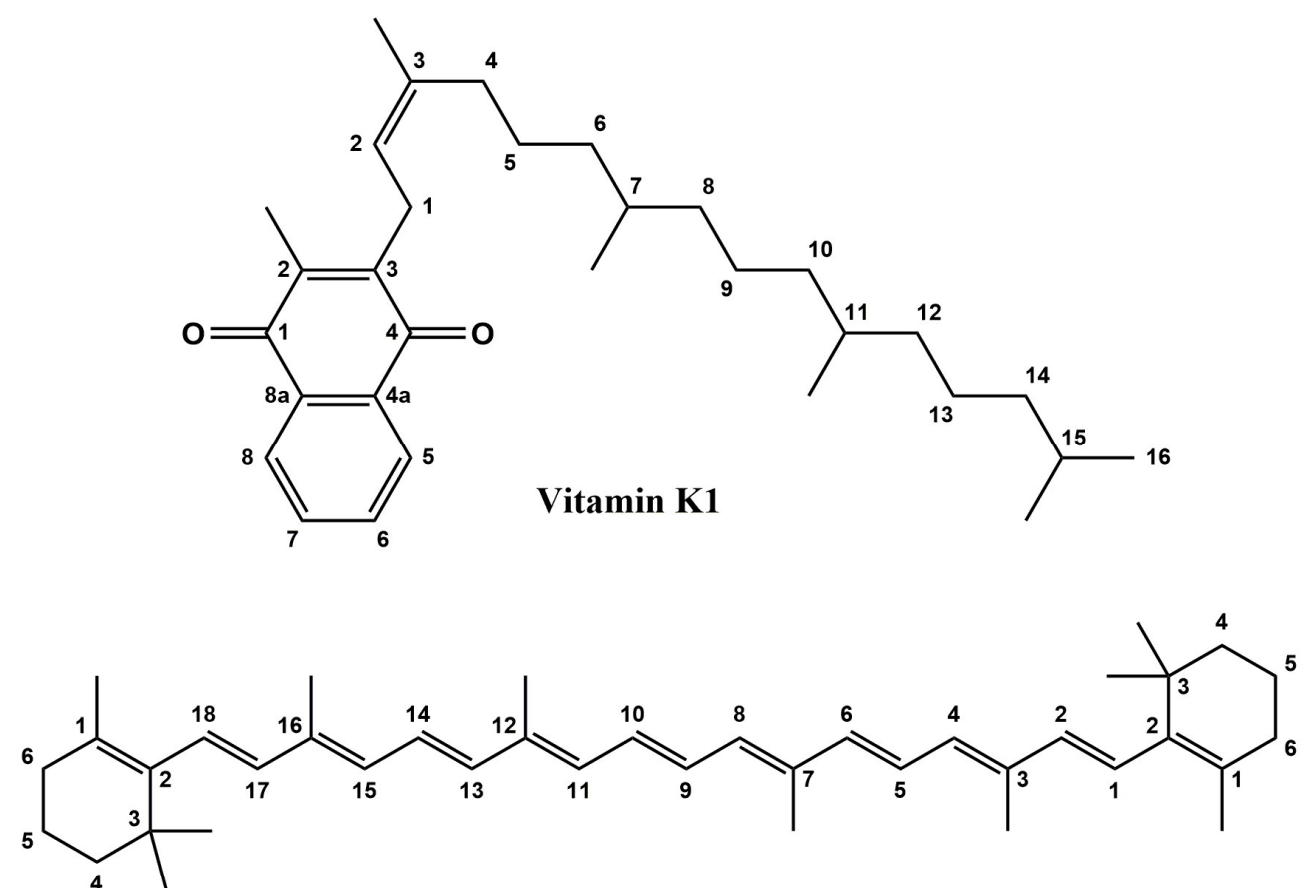

Beta-carotene

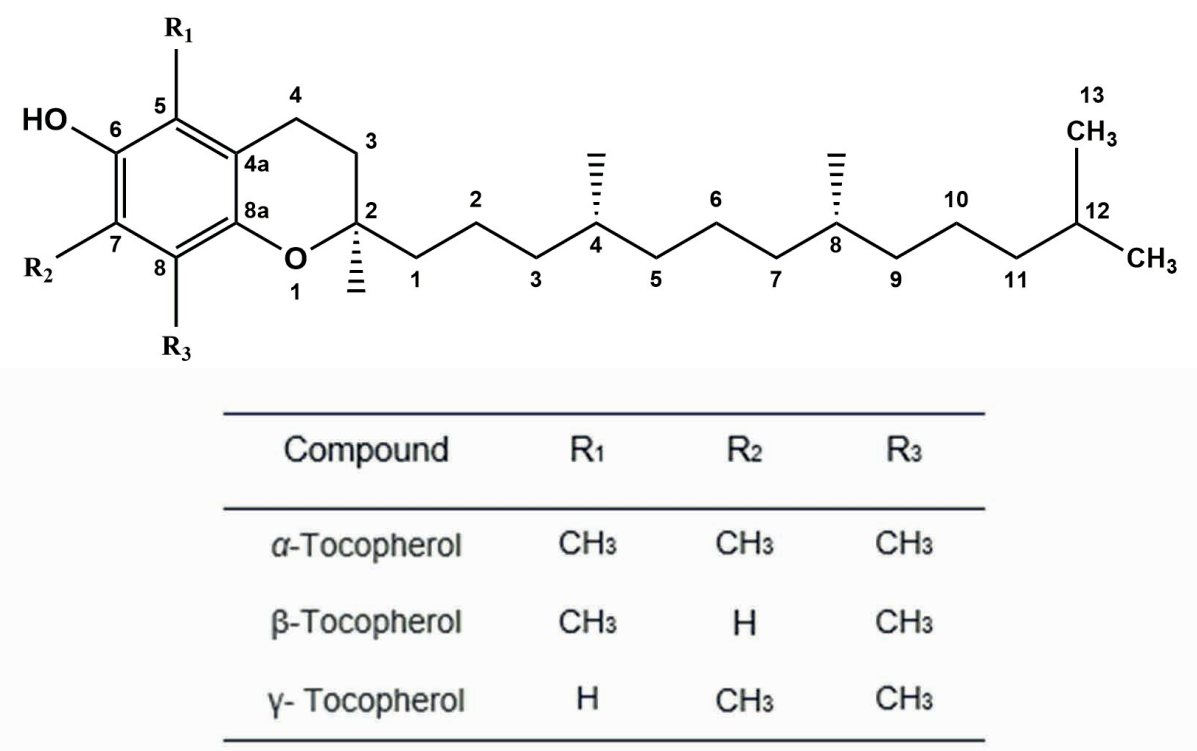

Figure 3.

Structural formulas of tocopherols present in Opuntia oil

\section{Polyphenols}

Koubaa et al. reported that Opuntia seed oil from the region of Sfax (Tunisia), extracted using $\mathrm{SC}-\mathrm{CO}_{2}$, was richer in polyphenols $(172.2 \pm 11.9 \mu \mathrm{g} \mathrm{GAE} / \mathrm{g}$ oil) than the oil extracted with hexane $(76.0 \pm 6.9 \mu \mathrm{g}$ $\mathrm{GAE} / \mathrm{g}$ oil). The $\mathrm{SC}-\mathrm{CO}_{2}$ technique led to the extraction of more polyphenols ( 45 compounds) than hexane (11 compounds). In general, the abundant polyphenol molecules in this oil are catechol, cinnamic acid, 3-phenylpropionic acid, syringic acid, psoralen, sinapaldehyde, 3'-O-methylcatechin, (+)-gallocatechin, 4'-O-methyl-(-)-epicatechin-3'$\mathrm{O}$-glucuronide, bisdemethoxycurcumin and viscutin 1 (fig. 4) [10]. In another study, it was shown that $O$. ficus-indica seed oil consists of a total phenolic content of $551.0 \pm 0.3 \mathrm{mg} \mathrm{GAE} / \mathrm{L}$ [38]. A study carried out by Khémiri et al. on O. ficus-indica seed oil from Tunisia indicated that this oil has a carotenoid content of $10.520 \mathrm{mg} / \mathrm{kg}$ oil, total chlorophyll 
content of $4.57 \mathrm{mg} / \mathrm{kg}$ oil, a flavonoid content of $3.1 \mathrm{mg} \mathrm{QE} / \mathrm{g}$ oil and total phenolic content of $26.5 \mathrm{mg} \mathrm{GAE} / \mathrm{g}$ oil [39]. Also, a study conducted on O. dillenii from Morocco showed that it is rich in polyphenols (518.18 $\pm 14.36 \mathrm{mg} \mathrm{GAE} / \mathrm{kg}$ oil) [40].

\section{Volatile compounds}

A study conducted by Karabagias et al. on O. ficus-indica seed oil showed that this oil is made up of 221 volatile compounds. These compounds could be grouped into alcohol (9.13\%), acids (2.70\%), esters (2.82\%), aldehydes $(62.72 \%)$, ketones $(4.38 \%)$, hydrocarbons (5.06\%) and other compounds (12.71\%). The most dominant volatile compounds are aldehydes, and among them, pentanal, 2-propenal, hexanal, heptanal, 2-hexenal, octanal, 2-octenal, 2-heptenal, and trans-4,5-epoxy-(E)-2-decenal, nonanal 2,4-decadienal (E recorded the highest proportions) [38]. Also, Zito et al. reported that O. ficus-indica seed oil obtained from Sanguigna cultivar grown in Sicily, contains mainly hydrocarbons (38.5\%), fatty acids and derivatives (31.9\%), and terpenes (12.4\%), while the seed oil obtained from Surfarina cultivar grown in the same region contains higher contents of fatty acids and derivatives (68.9\%), followed by terpenes (10.9\%) [41].

\section{BIOLOGICAL PROPERTIES OF OPUNTIA SEED OIL}

In last few years, researchers have been interested in Opuntia oils. Moreover, the oil from O. ficus-indica seeds has been more studied than the one from O. dillenii seeds (fig. 5).

\section{Antioxidant effect}

\section{In vitro studies}

Ramirez-Moreno et al. in Mexico evaluated the antioxidant activity of O. ficus-indica seed oil extracted by three different solvents (ethyl acetate, ethanol and hexane), and showed that these oils have a significant scavenging activity against the 2,2-diphenyl-1-picrylhydrazyl radical (DPPH). The oil extracted with ethyl acetate had the highest antioxidant activity $(274 \mu \mathrm{mol}$ $\mathrm{TE} / 20 \mathrm{mg}$ of extract), followed by ethanol $(247 \mu \mathrm{mol}$ $\mathrm{TE} / 20 \mathrm{mg}$ of extract), and hexane which had the lowest values. These results showed that the type of solvent employed for the extraction could influence the antioxidant effect of these oils [25]. This activity was observed in another study in Mexico, in which a different extraction method was used: the ultrasound. The results of the antioxidant activity showed an $\mathrm{IC}_{50}$ of $289 \mu \mathrm{mol} \mathrm{TE} / 100 \mathrm{~g}$ and $66.25 \mathrm{mg} \mathrm{AAE} / 100 \mathrm{~g}$ for DPPH and 2,2'-azino-bis(3-ethylbenzothiazoline6-sulfonic acid) $\left(\mathrm{ABTS}^{+}\right)$, respectively [42]. Besides, the antioxidant property of the Moroccan O. ficus-indica seed oil (from Oujda) was studied employing a DPPH test. The data showed that the antioxidant property of this oil $\left(\mathrm{IC}_{50}=19.79 \pm 0.023 \mu \mathrm{l} / \mathrm{ml}\right)$ was greater than that of the ascorbic acid used as a reference $\left(\mathrm{IC}_{50}=16.56 \pm 0.019 \mu \mathrm{g} / \mathrm{ml}\right)$. Also, the antioxidant potencial of the seed oil was shown to be concentration-dependent [14]. Ali et al. evaluated the Moroccan O. ficus-indica seed oil and showed that it displays a strong antioxidant property via an $\mathrm{IC}_{50}$ value of $0.96 \mathrm{mg} / \mathrm{ml}$. Therefore, the overall productivity of this oil for DPPH scavenging is $90 \mathrm{~min}[(86.20 \pm 0.13 \%)$, $6 \mathrm{mg} / \mathrm{ml}]$, and it was smaller than that of ascorbic acid [(97.12 $\pm 0.57 \%), 1.6 \mathrm{mg} / \mathrm{ml}]$. Besides, the antioxidant potential of this oil rose in proportion to its amount in the solution [43]. In another work, the antioxidant activity of two fractions of $O$. ficus-indica seed oil from Tunisia (glyceride and unsaponifiable) extracted by cold pressure, was tested by three methods: DPPH, ABTS, and $\beta$-carotene bleaching. The scavenging effect on the DPPH radical of the unsaponifiable and glyceridic fractions of O. ficus-indica seed oil was significantly different $\left(\mathrm{IC}_{50}=11.5\right.$ and $13.5 \mathrm{mg} / \mathrm{ml}$, respectively). Besides, the antioxidant activity of the glyceridic and unsaponifiable fractions of O. ficus-indica seed oil on the ABTS radical were also substantially different $\left(\mathrm{IC}_{50}=25.4\right.$ and $15 \mathrm{mg} / \mathrm{ml}$, respectively). Results displayed that O. ficus-indica oil fractions prevent the bleaching of $\beta$-carotene at various degrees. On the contrary to the findings of the ABTS test, the unsaponifiable fraction seems to be more effective against the $\beta$-carotene bleaching. Therefore, the unsaponifiable fraction showed a greater capacity $\left(\mathrm{IC}_{50}=5 \mathrm{mg} / \mathrm{ml}\right)$ in scavenging ABTS than the glyceridic fraction $\left(\mathrm{IC}_{50}=17.5 \mathrm{mg} / \mathrm{ml}\right)$ [44]. In another study, the antioxidant activity of the O. ficus-indica seed oil from Tunisia was evaluated, using the $\beta$-carotene bleaching and DPPH radical scavenging tests. The results demonstrated a significant antioxidant property of this seed oil, which is superior to the ascorbic acid and butylated hydroxytoluene (BHT) used as references [22]. Also, in another work, the seed oil from O. ficus-indica showed a high antioxidant activity in vitro $(84.00 \pm 0.01 \%)$ [38]. The red and yellow O. ficus-indica seed oils obtained using Soxhlet as an extraction 
<smiles>O=C(O)CCc1ccccc1</smiles>

Cinnamic acid<smiles>O=C(O)CCc1ccccc1</smiles>

3-Phenylpropionic acid<smiles>Oc1ccccc1O</smiles>

Catechol<smiles>COc1cc(C(=O)O)cc(OC)c1O</smiles>

(+)-gallocatechin<smiles>Cc1ccc([C@@H]2Oc3cc(O)cc(O)c3C[C@H]2O)cc1O</smiles><smiles>COc1cc(CCC=O)cc(OC)c1O</smiles>

Sinapaldehyde<smiles>O=c1ccc2cc3ccoc3cc2o1</smiles><smiles>COc1cc(C2Oc3cc(O)cc(O)c3CC2O)ccc1O</smiles><smiles>COc1ccc(C2Oc3cc(O)cc(O)c3CC2O)cc1OC1O[C@H](C(=O)O)[C@@H](O)[C@H](O)[C@H]1O</smiles>

4'-O-methyl-(-)-epicatechin-3'-O-glucuronide<smiles>O=C(/C=C/c1ccc(O)cc1)CC(=O)/C=C/c1ccc(O)cc1</smiles><smiles></smiles>

Figure 4.

Structural formulas of polyphenols present in Opuntia oil 


\section{Biological Properties}

O. ficus-indica seeds oil

\author{
- Antioxidant effect \\ - Antidiabetic effect \\ - Anti-inflammatory effect \\ - Antibacterial effect \\ - Antifungal effect \\ - Gastroprotective activity \\ - Hypolipidemic effect \\ - prevents weight loss
}

\section{O. dillenii seeds oil}

\author{
- Antioxidant effect \\ - Antidiabetic effect \\ - prevents weight loss \\ - Hepatoprotective effect \\ - antihyperlipidemic effect
}

Figure 5.

Biological effects of O. ficus-indica and O. dillenii

procedure showed an activity that is more promising in the DPPH test with $\mathrm{IC}_{50}$ values of 40.9 and $50.2 \mu \mathrm{g} / \mathrm{ml}$, respectively. The Opuntia red seed oil sample also showed a higher $\mathrm{ABTS}^{+}$radical trapping potential with an $\mathrm{IC}_{50}$ value of $48.5 \mu \mathrm{g} / \mathrm{ml}$, followed by yellow variate oil with an $\mathrm{IC}_{50}$ value of $54.3 \mu \mathrm{g} / \mathrm{ml}$. The analysis of the FRAP test results indicated that the red seed oil sample has a higher ferric reducing ability $(65.9 \mu \mathrm{M}$ $\mathrm{Fe}(\mathrm{II}) / \mathrm{g}$ ) while compared to the positive control BHT $(63.2 \mu \mathrm{M} \mathrm{Fe}(\mathrm{II}) / \mathrm{g})$. Both values were recorded at an oil concentration of $2.5 \mathrm{mg} / \mathrm{ml}$. Also, in the $\beta$-carotene bleaching test, the lipid peroxidation protection was demonstrated with $\mathrm{IC}_{50}$ values ranging from 67.5 to $97.2 \mu \mathrm{g} / \mathrm{ml}$ and from 60.3 to $78.2 \mu \mathrm{g} / \mathrm{ml}$, respectively, for the red seed oil and the yellow seed oil at 30 and 60 minutes of incubation [45]. A study carried out by Khémiri et al. on the oil of O. ficus-indica seeds from Tunisia, indicated that the oil has an important scavenging activity against ABTS and DPPH in comparison with the vitamin C. They registered, respectively, $87.42 \pm 0.11$ and $88.41 \pm 0.59 \mathrm{VCE} / \mathrm{g}$ oil [39]. The antioxidant property of $O$. dillenii seed oil was assessed by $\beta$-carotene bleaching and DPPH tests. The results demonstrated the significant antioxidant potential of this Opuntia seed oil, which is almost comparable to the references (BHT and ascorbic acid). This antioxidant activity was also concentration-dependent [30]. In another work, the antioxidant activity of $O$. dillenii seed oil was assessed employing a DPPH scavenging assay. The data demonstrated that its antioxidant properties $(27.210 \pm 0.075 \mu \mathrm{l} / \mathrm{ml})$ are greater than the one of the ascorbic acid $(16.560 \pm 0.019 \mu \mathrm{g} / \mathrm{ml})$. Besides, the antioxidant activity of this oil has also been shown to be concentration-dependent [46]. The oil extracted by the $\mathrm{SC}-\mathrm{CO}_{2}$ method or hexane showed a high percentage of inhibition. To test the antioxidant potential of phenolic compounds derived from O. dillenii seed oil, the DPPH free radical assay was used. The results obtained demonstrated that the DPPH inhibition increased in proportion to the extract concentration. The $\mathrm{IC}_{50}$ values obtained were respectively $3,5,9$, and $10 \mu \mathrm{g} / \mathrm{ml}$ for ascorbic acid, BHA, hexaneextracted seed oil, and seed oil extracted with SC$\mathrm{CO}_{2}$ [47]. Besides, the antioxidant activity of O. dillenii seed oil from Iraq was determined. Cactus seed oil showed a strong antioxidant capacity estimated by its ability to reduce oxidation. Besides, the obtained results have shown the powerful trapping activity of cactus oil compared to ascorbic acid. The DPPH reduction activities obtained were respectively 36.5 to $78.1 \%$ and 46.5 to $81.3 \%$ for the cactus seed oil and ascorbic acid at concentrations of 10,50, 100, 500, and $1000 \mu \mathrm{g} / \mathrm{ml}[48]$.

\section{Antidiabetic effect}

\section{In vitro study}

There was a concentration-dependent influence on the carbohydrate hydrolysing enzymes in all of the tested samples. The red O. ficus-indica oil showed the 
highest inhibitory activity with an $\mathrm{IC}_{50}$ value lower than that reported for the positive control acarbose (32.7 vs $50.0 \mu \mathrm{g} / \mathrm{ml}$, respectively). This extract also showed a significant activity against $\alpha$-glucosidase with an $\mathrm{IC}_{50}$ value of $42.4 \mu \mathrm{g} / \mathrm{ml}$. Besides, the results obtained with the yellow $O$. ficus-indica oil are highly notable, with $\mathrm{IC}_{50}$ values of 52.5 and $44.6 \mu \mathrm{g} / \mathrm{ml}$ against $\alpha$-amylase and $\alpha$-glucosidase, respectively [29] .

\section{In vitro studies}

A study conducted in Morocco by Berraaouan et al. showed that the oil of O. ficus-indica seeds, at an amount of 1 and $2 \mathrm{ml} / \mathrm{kg}$, improves oral glucose tolerance. It significantly reduces the postprandial hyperglycaemia (60 min after glucose loading), with a percentage of $40.33 \%$ and $16.01 \%$ in healthy rats and streptozotocin-induced diabetic rats, respectively. Also, the seed oil of O. ficus-indica significantly decreased the intestinal absorption of glucose with a percentage of $25.42 \%$ [49]. In another study, the treatment of mice, injected by an antidiabetogenic agent (alloxan), with the oil of O. ficus-indica seed at an amount of $2 \mathrm{ml} / \mathrm{kg}$ decreased the incidence of mortality caused by alloxan. Besides, this oil attenuated the increase in blood glucose and decreased bodyweight loss in these mice, in comparison with the mice treated after being injected by this diabetogenic agent. Besides, O. ficus-indica seeds oil attenuated the destruction of pancreatic islets induced by alloxan. Indeed, oral administration of this oil in mice injected with alloxan significantly prevented the pancreatic lesions induced by this product. It preserved the diameter and the surface of the islets, as well as the insular number of cells in the normal state while compared to untreated mice [43]. The addition of the O. ficus-indica oil to the diet of rats at an amount of $25 \mathrm{~g} / \mathrm{kg}$ showed a significant hypoglycaemic effect, according to research carried out on O. ficus-indica grown in Tunisia. Indeed, a substantial decrease in blood glucose $(22 \%)$ and a significant improvement in the concentration of glycogen in the liver and muscles was produced by the enrichment of the diet with the oil [50]. Another study conducted by Bouhrim et $a l$. showed that the administration of $O$. dillenii seed oil at a dose of 1 and $2 \mathrm{ml} / \mathrm{kg}$ for four weeks significantly reduced the hyperglycaemia in diabetic rats. Besides, this oil reduced the urinary glucose levels and increased the hepatic glycogen levels during the treatment period. At the end of this period, an improvement of diabetic symptoms (intake and food, urinary volume) was shown [51]. Moreover, O. dillenii seed oil had a major antidiabetogenic effect by minimizing the loss of body weight, the increase in blood sugar levels and the mortality rate in albino mice caused by alloxan [40]. In a study on the mechanisms of action of the antihyperglycaemic effect of $O$. dillenii seeds oil, the results showed that it attenuated significantly the postprandial hyperglycaemia in normal and STZ-diabetic rats. Indeed, O. dillenii seed oil significantly decreased the intestinal $\mathrm{D}$-glucose absorption in situ. The ex vivo test (using chambers) showed that the $O$. dillenii seed oil significantly blocks the SGLT1 $\left(\mathrm{IC}_{50}=60.24 \mu \mathrm{g} / \mathrm{ml}\right)$. Moreover, O. dillenii seed oil induced a significant inhibition of the intestinal $\alpha$-glucosidase $\left(\mathrm{IC}_{50}=278.00 \pm 0.01 \mu \mathrm{g} / \mathrm{ml}\right.$ ) and the pancreatic $\alpha$-amylase $\left(\mathrm{IC}_{50}=0.81 \pm 0.09 \mathrm{mg} / \mathrm{ml}\right)$ in vitro. A significant decrease of the postprandial hyperglycaemia was observed in sucrose/starch-loaded normal and STZ-diabetic ODSO-treated rats [52].

\section{Anti-inflammatory effect}

\section{In vivo study}

The anti-inflammatory action of the O. ficus-indica seed oil has been shown in a study in Morocco. Indeed, the anti-inflammatory activity was evaluated in carrageenan and inflammatory edema of the hind paw induced by experimental trauma in Wistar rats. At a dose of $200 \mathrm{mg} / \mathrm{kg}$, O. ficus-indica seed oil significantly inhibited the development of the oedema after $1.5,3$, and 6 hours with a reduction of $72.49 \%$, $63.94 \%$ and $92.01 \%$, respectively. Also, the evaluation of the anti-inflammatory activity showed a significant inhibition of the rat paw oedema after $6 \mathrm{~h}$ with a reduction of $87.52 \%$ and $69.10 \%$ at a dose of $200 \mathrm{mg} / \mathrm{kg}$ and $300 \mathrm{mg} / \mathrm{kg}$ of the O. ficus-indica seeds oil, respectively [53].

\section{Antibacterial effect}

\section{In vitro study}

As far as we know, only two studies have been conducted to evaluate the antibacterial properties of the $O$. $f i$ cus-indica seed oil. In the first study, the results showed that the oil extracted with ethanol had a significant antibacterial activity in many bacterial strains and with different inhibition zone diameters. It had a significant antibacterial effect against a wide range of bacteria such as Escherichia coli O58:H21 (11.4 $\pm 0.9 \mathrm{~mm})$, Staphylococcus aureus $(11.1 \pm 1.1 \mathrm{~mm})$, Listeria monocytogenes $(11.4 \pm 0.9 \mathrm{~mm})$ and Pseudomonas aeruginosa $(15.1 \pm 2.0 \mathrm{~mm})$ [25]. In another work, the 
antibacterial property of the O. ficus-indica seed oil was tested against two Gram-negative bacteria and one Gram-positive bacteria. The data of this work showed that this seed oil exhibited an antibacterial activity against Staphylococcus aureus and Escherichia coli. But, this effect was not noticed against Pseudomonas aeruginosa [42]. The disk diffusion approach was used to assess the antimicrobial activity on some selected foodborne pathogens, namely: Salmonella typhimurium, Enterococcus faecalis, S. aureus, E. coli and $P$. aeruginosa. Results showed that some $O$. ficus-indica oil fractions inhibit the microorganism growth, depending on the strain sensibility and the fraction nature. The glyceridic fraction did not show an antimicrobial property, whereas the unsaponifiable fraction was active against all the studied pathogens. Therefore, the glyceride-free extract contains interesting bioactive compounds as they can inhibit certain resistant strains especially the Gramnegative ones like Escherichia coli [44]. Also, the antibacterial activity of $O$. ficus-indica oil from Tunisia was evaluated against Enterobacter cloacae. The results revealed that this oil was able to inhibit this bacterium with an inhibition diameter of $15.5 \mathrm{~mm}$. The positive controls exhibited diameters of $23 \mathrm{~mm}$ for Ceftazidime CAZ30 and $10 \mathrm{~mm}$ for Colicine CL50. Besides, the results show that the oil tested had a high bactericidal activity of about $1280 \mathrm{AU} / \mathrm{ml}$. The MBC and MIC values of the oil on Enterobacter cloacae were $1 / 128$ and $1 / 64$, respectively [54].

\section{Gastroprotective activity}

\section{In vitro study}

Khémiri et al. investigated the therapeutic effect of $O$. ficus-indica cold-pressed seed oil on an ethanolproduced gastric ulcer in rats. The oil was very efficient in the protection of the cytoarchitecture and the gastric mucosa function against the serious damages induced by ethanol intake. It was demonstrated that the pre-treatment with O. ficus-indica seed oil can significantly reduce the ulcerated areas with a high ulcer inhibition percentage. Moreover, it was found that the oil could stimulate mucus production, reduce gastric juice volume and may increase $\mathrm{pH}$ values. To confirm the gastroprotective efficiency of O. ficus-indica oil, a histopathological examination of gastric mucosae biopsies was performed, using hematoxylin and eosin stain. This efficiency was proven against ethanol that leads to the appearance of several symptoms such as inflammation and severe damages like lesions, necrosis, erosions, bleeding and ulcers. Besides, the treatment with O. ficus-indica oil reduces, in a dose-dependent manner, the surface of the ulcerated areas produced by ethanol. It also leads to a time gain in the healing process, with a healing rate of $91 \%$ on the second day and $99 \%$ on the third day. On the fourth day, a complete recovery under the oil treatment was observed. The therapeutic effects of O. ficus-indica oil on gastric ulcers could be mediated by its diverse bioactive compounds [39].

\section{Antifungal effect}

\section{In vitro studies}

Ramirez-Moreno et al. studied the antifungal potential of $O$. ficus-indica seed oil using two different species of fungi. The oil has significantly inhibited the development of Saccharomyces cerevisiae and Candida albicans with an inhibition zone diameter of $40.3 \pm 4.5 \mathrm{~mm}$ and $11.0 \pm 1.8 \mathrm{~mm}$, respectively. This property can be attributed to the effect of the polyunsaturated fatty acids present in this oil [25]. Besides, the antifungal activity of O. ficus-indica oil from Tunisia was evaluated against three opportunistic cutaneous moulds (Fusarium, Aspergillus and Penicillium), and two yeasts (Candida sake and Candida parapsilosis). The findings revealed that this oil was capable of inhibiting the growth of pathogenic fungi. The inhibition zone diameter of the genus Candida obtained with O. ficus-indica oil ranged from 14 to $16.5 \mathrm{~mm}$, respectively, against C. parapsilosis and C. sake, while $35.5 \mathrm{~mm}$ was obtained with Voriconazole and $10 \mathrm{~mm}$ was obtained with Amphotericin B. On the one hand, the growth of two of the three tested species of yeast (C. sake and C. parapsilosis) was inhibited with high MBC and MIC values (1/64 and 1/32 for both sensitive yeasts, respectively). On the other hand, the growth of the three fungal pathogens, Fusarium, Aspergillus and Penicillium, examined with the same MIC and MBC values of $1 / 4$ and $1 / 8$, may be decreased by oil [54].

\section{Hypolipidemic effect}

\section{In vivo study}

According to the research carried out on O. ficus-indica from Tunisia, supplementing rats food with the seed oil at an amount of $25 \mathrm{~g} / \mathrm{kg}$ decreased low-density lipoprotein (LDL) and blood cholesterol, without any remarkable variation in high-density lipoprotein values (HDL) during the treatment [55]. In another 
work performed by Ennouri et al., dietary supplementation by O. ficus-indica seed oil was shown to be effective in reducing the atherogenic risk factors in rats at an amount of $25 \mathrm{~g} / \mathrm{kg}$. The addition of this oil in the diet produced a significant lipid-decreasing effect in the treated animals, as compared with the control group receiving a standard diet. Indeed, a very pronounced decrease in total cholesterol and a significant rise in the ratio of HDL cholesterol/total cholesterol were noticed, as compared the treated group to the control. Moreover, the atherogenic index in rats treated with the oil-enriched diet was significantly lower than in the control group [56]. The treatment of diabetic rats for four weeks with oil quantities of 1 and $2 \mathrm{ml} / \mathrm{kg}$ significantly reduced the cholesterol and the triglycerides amount [52]. Also, Bouhrim et $a l$. showed that the daily intake of the seed oil of $O$. dillenii significantly attunes the increase in the cholesterol, triglycerides, HDL cholesterol/total cholesterol ratio, and the atherogenic index levels in albino mice that were fed with a high-fat diet. Indeed, it did not affect the HDL cholesterol amount [40].

\section{Bodyweight}

\section{In vivo study}

The supply of O. ficus-indica seed oil in mice treated with alloxan significantly inhibited the bodyweight loss induced by this diabetogenic agent compared with mice treated with alloxan alone [49]. In another study, the supplementation of rat food with Opuntia seed oil $(25 \mathrm{~g} / \mathrm{kg})$ during 28 days of treatment induced a linear rise in body weight of rats fed with a high-fat diet, in comparison with the group that has received a standard diet [55]. In a work realized by Bouhrim et al., the $O$. dillenii seed oil was also found to be enhancing the growth performance by decreasing the relative liver index and by increasing body weight gain in rats with $\mathrm{CCl}_{4}$ hepatotoxicity after 14 days of treatment [56]. Moreover, in another study, the O. dillenii seed oil administration with alloxan significantly inhibited the body weight loss in treated groups while compared to the group treated with alloxan only [40].

\section{Hepatoprotective effect}

\section{In vivo study}

According to a study performed in Morocco, O. dillenii seed oil was found to exert a hepatoprotective effect in rats by diminishing alanine aminotransferase, aspartate aminotransferase and alkaline phosphatase activities in plasma, in comparison with rats treated only by $\mathrm{CCl}_{4}$. Besides, $O$. dillenii seed oil ameliorated the excretory function of the liver, and decreased the total and the direct bilirubin plasma levels. Moreover, $O$. dillenii seed oil also ameliorated the metabolic function of the liver by the restoration of triglycerides, glucose and VLDL-c to normal values, while compared to the $\mathrm{CCl}_{4}$ control group [52]. Furthermore, the treatment of diabetic rats for four weeks with an $O$. dillenii seed oil in a quantity of 1 and $2 \mathrm{ml} / \mathrm{kg}$ protected the hepatotoxicity produced by streptozotocin in diabetic rats by the reduction in ALT and AST [52].

\section{Toxicology and safety of Opuntia seed oils}

In a study performed by Ali et al. to evaluate the toxicity of O. ficus-indica oil in mice, it was shown that it is not toxic. Indeed, after intraperitoneal injection or oral administration of the oil at the doses of 1000,3000 , or $5000 \mu \mathrm{l} / \mathrm{kg}$, no abnormal behavioural or autonomous effects were observed and no mortality happened during the 14 days of the treatment [49]. In another study, a low toxicity of O. ficus-indica seed oil was shown. The test showed that the lethal doses $\left(\mathrm{LD}_{50}\right)$ are $4300 \mu \mathrm{l} / \mathrm{kg}$ and $2720 \mu \mathrm{l} / \mathrm{kg}$ for oral administration and intraperitoneal injection, respectively [57]. From these studies it can be concluded that the O. ficus-indica seed oil is not toxic even at high doses [58]. Khémiri et al. evaluated the acute toxicity of the O. ficus-indica seed oil in adult rats. The results showed that the oil at a dose of $3500 \mu \mathrm{l} / \mathrm{kg}$ and $7000 \mu \mathrm{l} / \mathrm{kg}$ did not exhibit any symptoms of mortality or toxicity in the orally treated animals during the five-day experimental period [39]. The toxicity of $O$. dillenii seed oil was evaluated by Bouhrim et al. and the results demonstrated its safety. Indeed, this study showed that this oil does not produce any mortality or signs of toxicity after a single-dose administration in mice. Additionally, the daily intake of the $O$. dillenii seed oil during four weeks does not induce a significant variation in the biochemical parameters and the body weight of rats while compared with the control group. Besides, the cell viability of HepG2 did not change in the presence of $O$. dillenii seed oil [59].

\section{CONCLUSION AND PERSPECTIVES}

This review has shown that the seed oils of $O$. dillenii and O. ficus-indica have chemical compositions rich in a set of molecules, mostly unsaturated fatty acids, 
phytosterols, tocopherols and polyphenols. Biologically active molecules allow the studied oil to exert several biological and pharmacological activities (antioxidant, antidiabetic, antibacterial, antifungal, anti-inflammatory, hepatoprotective, hypoglycaemic, hypolipidemic and gastroprotective), and to alleviate the decline of body weight. Moreover, most of the studies focus on O. ficus-indica, while $O$. dillenii has drawn the attention of researchers only in the last few years. Besides, the studies that have been carried out on these two species have not indicated a significant difference in their effectiveness. Therefore, more studies should be undertaken in the future to evaluate more biological activities of $O$. dillenii seed oil, and to confirm the uses of these two plants in folk medicine. Until now, all the mentioned biological effects have been carried out on the whole constituents of the oil. A strategy of molecule isolation, identification and testing are necessary.

Ethical approval: The conducted research is not related to either human or animal use.

Conflict of interest: Authors declare no conflict of interest.

\section{REFERENCES}

1. Stintzing FC, Carle R. Functional properties of anthocyanins and betalains in plants, food, and in human nutrition. Trends Food Sci Technol 2004; 15(1):19-38. doi: https://dx.doi.org/10.1016/j. tifs.2003.07.004

2. Hegwood DA. Human health discoveries with Opuntia sp. (Prickly Pear). Hort Science 1990; 25(12):1515-1516.

3. Chang SF, Hsieh CL, Yen GC. The protective effect of Opuntia dillenii Haw fruit against lowdensity lipoprotein peroxidation and its active compounds. Food Chem 2008; 106(2):569575. doi: https://dx.doi.org/10.1016/j.foodchem.2007.06.017

4. Medina EMD, Rodríguez EMR, Romero CD. Chemical characterization of Opuntia dillenii and Opuntia ficus-indica fruits. Food Chem 2007; 103(1):38-45. doi: https://dx.doi.org/10.1016/j. foodchem.2006.06.064

5. Shetty AA, Rana MK, Preetham SP. Cactus: a medicinal food. J Food Sci Technol 2012; 49:530-
536. doi: https://dx.doi.org/10.1007/s13197-0110462-5

6. Kabas O, Ozmerzi A, Akinci I. Physical properties of cactus pear (Opuntia ficus india L.) grown wild in Turkey. J Food Eng 2006; 73(2):198202. doi: https://dx.doi.org/10.1016/j.jfoodeng.2005.01.016

7. Kumar D, Sharma PK. A review on Opuntia species and its chemistry. Pharmacognosy, pharmacology and bioapplications. Curr Nutr Food Sci 2020; 16(8):1227-1244.

8. Silva MA, Albuquerque TG, Pereira P, Ramalho R, Vicente F, Oliveira MBPP, Costa HS. Opuntia ficus-indica (L.) Mill.: A multi-benefit potential to be exploited. Molecules 2021; 26(4):951. doi: https://dx.doi.org/10.3390/molecules26040951

9. Ghazi Z, Ramdani M, Fauconnier ML, El Mahi B, Cheikh R. Fatty acids sterols and vitamin E composition of seed oil of Opuntia ficus indica and Opuntia dillenii from Morocco. J Mater Environ Sci 2013; 4(6):967-972.

10. Koubaa M, Mhemdi H, Barba FJ, Angelotti A, Bouaziz F, Chaabouni SE, Vorobiev E. Seed oil extraction from red prickly pear using hexane and supercritical $\mathrm{CO}_{2}$ : assessment of phenolic compound composition, antioxidant and antibacterial activities. J Sci Food Agric 2017; 97(2):613-620. doi: https://dx.doi.org/10.1002/ jsfa.7774

11. De Castro MDL, Garcia-Ayuso LE. Soxhlet extraction of solid materials: an outdated technique with a promising innovative future. Anal Chim Acta 1998; 369(1-2):1-10. doi: https://dx.doi. org/10.1016/S0003-2670(98)00233-5

12. Matthäus B, Özcan MM. Habitat effects on yield, fatty acid composition and tocopherol contents of prickly pear (Opuntia ficus-indica L.) seed oils. Sci Hortic (Amsterdam) 2011; 131(1):95-98. doi: https://dx.doi.org/10.1016/j.scienta.2011.09.027

13. Daoudi NE, Bouhrim M, Ouassou H, Legssyer A, Mekhfi H, Ziyyat A et al. Inhibitory effect of roasted/unroasted Argania spinosa seeds oil on $\alpha$-glucosidase, $\alpha$-amylase and intestinal glucose absorption activities. South African J Bot 2020; 135:413-420. doi: https://dx.doi.org/10.1016/j. sajb.2020.09.020 
14. Gharby S, Harhar H, Charrouf Z, Bouzobaa Z, Boujghagh M, Zine S. Physicochemical composition and oxidative stability of Opuntia ficusindica seed oil from Morocco. Acta Hortic 2015; 1067:83-88. doi: https://dx.doi.org/10.17660/ActaHortic.2015.1067.11

15. Harhar H, Gharby S, Guillaume D, Charrouf Z. Effect of argan kernel storage conditions on argan oil quality. Eur J Lipid Sci Technol 2010; 112(8):915-920. doi: https://dx.doi.org/10.1002/ ejlt.200900269

16. Zine S, Gharby S, El Hadek M. Physicochemical characterization of Opuntia ficus-indica seed oil from Morocco. Biosci Biotechnol Res Asia 2013; 10(1):1-7. doi: http://dx.doi.org/10.13005/ bbra/1099

17. Morales P, Ramírez-Moreno E, de Cortes Sanchez-Mata M, Carvalho AM, Ferreira ICFR. Nutritional and antioxidant properties of pulp and seeds of two xoconostle cultivars (Opuntia joconostle FAC Weber ex Diguet and Opuntia matudae Scheinvar) of high consumption in Mexico. Food Res Int 2012; 46(1):279-285. doi: https://dx.doi.org/10.1016/j.foodres.2011.12.031

18. Macheix J-J, Fleuriet A, Jay-Allemand C. Les composés phénoliques des végétaux: un exemple de métabolites secondaires d'importance économique. Lausanne. PPUR presses polytechniques, 2005.

19. Traber MG. Vitamin E regulatory mechanisms. Ann Rev Nutr 2007; 27:347-362. doi: https://dx.doi. org/10.1146/annurev.nutr.27.061406.093819

20. Manach C, Scalbert A, Morand C, Rémésy C, Jiménez L. Polyphenols: food sources and bioavailability. Am J Clin Nutr 2004; 79(5):727-747. doi: https://dx.doi.org/10.1093/ajcn/79.5.727

21. Simopoulos AP. The importance of the ratio of omega-6/omega-3 essential fatty acids. Biomed Pharmacother 2002; 56(8):365-379. doi: https:// dx.doi.org/10.1016/S0753-3322(02)00253-6

22. Ouerghemmi I, Bourgou S, Mejri H, Marzouk B, Tounsi MS. Study of essential and fixative oil chemical composition extracted from Opuntia ficus-indica seeds grown in Tunisia and its antioxidant activity. Riv Ital delle Sostanze Grasse 2013; 90(1):21-29.
23. Chougui N, Tamendjari A, Hamidj W, Hallal S, Barras A, Richard T, Larbat R. Oil composition and characterisation of phenolic compounds of Opuntia ficus-indica seeds. Food Chem 2013; 139(1-4):796-803. doi: https://dx.doi. org/10.1016/j.foodchem.2013.01.054

24. Adib S El, Slim S, Hamdeni E. Characterization and comparison of the three cultivars seed oil of Opuntia ficus-indica in Tunisia. Indo Amer J Pharm Sci 2015; 2(5):967-973.

25. Ramírez-Moreno E, Cariño-Cortés R, CruzCansino N del S, Delgado-Olivares L, ArizaOrtega JA, Montañez-Izquierdo VY et al. Antioxidant and antimicrobial properties of cactus pear (Opuntia) seed oils. J Food Qual 2017; 5:1-8. doi: https://dx.doi.org/10.1155/2017/3075907

26. Coşkuner Y, Tekin A. Monitoring of seed composition of prickly pear (Opuntia ficus-indica L.) fruits during maturation period. J Sci Food Agric 2003; 83(8):846-849. doi: https://dx.doi. org $/ 10.1002 /$ jsfa. 1423

27. Ennouri M, Evelyne B, Laurence M, Hamadi A. Food chemistry fatty acid composition and rheological behaviour of prickly pear seed oils. Food Chem 2005; 93(3):431-437.

28. Ramadan MF, Mörsel JT. Oil cactus pear (Opuntia ficus-indica L.). Food Chem 2003; 82(3):339345. doi: https://dx.doi.org/10.1016/j.foodchem.2004.10.020

29. Bhatt MR, Nagar PS. Evaluation of physicochemical property and fatty acid composition of Opuntia elatior seed oil. J Prof Assoc Cactus Develop 2013; 13-19.

30. Liu W, Fu YJ, Zu YG, Tong MH, Wu N, Liu XL, Zhang S. Supercritical carbon dioxide extraction of seed oil from Opuntia dillenii Haw. and its antioxidant activity. Food Chem 2009; 114(1):334339. doi: https://dx.doi.org/10.1016/j.foodchem.2008.09.049

31. Tlili N, Bargougui A, Elfalleh W, Triki S, Nasri N. Phenolic compounds, protein, lipid content and fatty acids compositions of cactus seeds. J Med Plants Rese 2011; 5(18):4519-4524. doi: https:// dx.doi.org/10.5897/JMPR.9000972

32. Belviranli B, Al-Juhaimi F, Özcan MM, Ghafoor K, Babiker EE, Alsawmahi ON. Effect of location 
on some physico-chemical properties of prickly pear (Opuntia ficus-indica L.) fruit and seeds. J Food Process Preserv 2019; 43(3):1-9. doi: https://dx.doi.org/10.1111/jfpp.13896

33. Ramadan MF, Mörsel J-T. Recovered lipids from prickly pear [Opuntia ficus-indica (L.) Mill] peel: a good source of polyunsaturated fatty acids, natural antioxidant vitamins and sterols. Food Chem 2003; 83(3):447-456. doi: https://dx.doi. org/10.1016/S0308-8146(03)00128-6

34. Mannoubi I El, Barrek S, Skanji T, Casabianca $\mathrm{H}$, Zarrouk H. Seed oil from Tunisia. Chem Nat Comp 2009; 45(5):521-524. doi: https://dx.doi. org/10.1007/s10600-009-9448-1

35. Gharby S, Harhar H, El Monfalouti H, Kartah B, Maata N, Guillaume D, Charrouf Z. Chemical and oxidative properties of olive and argan oils sold on the Moroccan market. A comparative study. Med J Nutrition Metab 2012; 5(1):3138. doi: https://dx.doi.org/10.3233/s12349-0110076-5

36. Gharby S, Harhar H, Guillaume D, Roudani A, Boulbaroud S, Ibrahimi M et al. Chemical investigation of Nigella sativa L. seed oil produced in Morocco. J Saudi Soc Agric Sci 2015; 14(2):172-7. doi: https://dx.doi.org/10.1016/j.jssas.2013.12.001

37. Mouden M. Effect of two extraction methods and harvest period and performance there statement of fatty oils of figs pear seed. Int J Pure Appl Biosci 2016; 4(1):1-8. doi: http://dx.doi. org/10.18782/2320-7051.2192

38. Karabagias VK, Karabagias IK, Gatzias I, Badeka AV. Prickly pear seed oil by shelf-grown cactus fruits: Waste or maste? Processes 2020; 8(2):1-11. doi: https://dx.doi.org/10.3390/pr802013

39. Khémiri I, Bitri L. Effectiveness of Opuntia ficus indica $\mathrm{L}$. inermis seed oil in the protection and the healing of experimentally induced gastric mucosa ulcer. Oxid Med Cell Longev 2019. doi: https://dx.doi.org/10.1155/2019/1568720

40. Bouhrim M, Daoudi NE, Ouassou H, Benoutman A, Loukili EH, Ziyyat A et al. Phenolic content and antioxidant, antihyperlipidemic, and antidiabetogenic effects of Opuntia dillenii
Seed Oil Sci World J 2020:8. doi: https://dx.doi. org/10.1155/2020/5717052

41. Zito P, Sajeva M, Bruno M, Rosselli S, Maggio A, Senatore F. Essential oils composition of two Sicilian cultivars of Opuntia ficus-indica (L.) Mill. (Cactaceae) fruits (prickly pear). Nat Prod Res 2013; 27(14):1305-1314. doi: https://dx.doi.org/1 $0.1080 / 14786419.2012 .734823$

42. Ortega-Ortega MA, Cruz-Cansino NS, AlanísGarcía E, Delgado-Olivares L, Ariza-Ortega JA, Amírezmoreno ER, Manríquez-Torres JJ. Optimization of ultrasound extraction of cactus pear (Opuntia ficus-indica) seed oil based on antioxidant activity and evaluation of its antimicrobial activity. J Food Qual 2017; 72:1-9 doi: https:// dx.doi.org/10.1155/2017/9315360

43. Berraaouan A, Abderrahim Z, Hassane M, Abdelkhaleq L, Mohammed A, Mohamed B. Evaluation of protective effect of cactus pear seed oil (Opuntia ficus-indica L. Mill.) against alloxaninduced diabetes in mice. Asian Pac J Trop Med 2015; 8(7):532-537. doi: https://dx.doi. org/10.1016/j.apjtm.2015.06.013

44. R'bia O, Chkioua C, Hellal R, Herchi W, Smiti SA. Antioxidant and antibacterial activities of Opuntia ficus-indica seed oil fractions and their bioactive compounds identification. Turkish J Biochem 2017; 42(4):481-491. doi: https://dx.doi. org/10.1515/tjb-2016-0200

45. Loizzo MR, Bruno M, Balzano M, Giardinieri A, Pacetti D, Frega NG et al. Comparative chemical composition and bioactivity of Opuntia ficus-indica sanguigna and surfarina seed oils obtained by traditional and ultrasound-assisted extraction procedures. Eur J Lipid Sci Technol 2019; 121(1):1-7. doi: https://dx.doi.org/10.1002/ ejlt.201800283

46. Ghazi Z, Ramdani M, Tahri M, Rmili R, Elmsellem H, El Mahi B, Fauconnier ML. Chemical composition and antioxidant activity of seeds oils and fruit juice of Opuntia ficus-indica and Opuntia dillenii from Morocco. J Mater Environ Sci 2015; 6(8):2338-2345. http://hdl.handle. net $/ 2268 / 189343$

47. Özcan MM, Al Juhaimi FY. Nutritive value and chemical composition of prickly pear seeds (Opuntia ficus-indica L.) growing in Turkey. Int 
J Food Sci Nutr 2011; 62(5):533-536. doi: https:// dx.doi.org/10.3109/09637486.2011.552569

48. Ali Alsaad AJ, Altemimi AB, Aziz SN, Lakhssassi N. Extraction and identification of cactus Opuntia dillenii seed oil and its added value for human health benefits. Pharmacogn J 2019; 11(3):579587. doi: https://dx.doi.org/10.5530/pj.2019.11.92

49. Berraaouan A, Ziyyat A, Mekhfi H, Legssyer A, Sindic M, Aziz M. Evaluation of antidiabetic properties of cactus pear seed oil in rats. Pharm Biol 2014; 52(10):1286-90. doi: https://dx.doi.org $/ 10.3109 / 13880209.2014 .890230$

50. Ennouri M, Fetoui H, Bourret E, Zeghal N, Attia $\mathrm{H}$. Evaluation of some biological parameters of Opuntia ficus-indica. 1. Influence of a seed oil supplemented diet on rats. Bioresour Technol 2006; 97:1382-1386. doi: https://dx.doi.org/10.1016/j. biortech.2005.07.010

51. Bouhrim M, Ouassou H, Loukili EH, Ramdani M, Mekhfi H, Legssyer A et al. Antidiabetic effect of Opuntia dillenii seed oil on streptozotocin-induced diabetic rats. Asian Pac J Trop Biomed 2019; 9(9):381-388. doi: https://dx.doi. org/10.4103/2221-1691.267639

52. Bouhrim M, Ouassou H, Boutahiri S, Daoudi NE, Mechchate H, Gressier B, Bnouham M. Opuntia dillenii (Ker Gawl.) Haw., seeds oil antidiabetic potential using in vivo, in vitro, in situ, and ex vivo approaches to reveal its underlying mechanism of action. Molecules 2021; 26(6):1677. doi: https:// dx.doi.org/10.3390/molecules 26061677

53. El Hachimi F, Hajjaj G, Bendriss A, Cherrah Y, Alaoui K. Anti-inflammatory activity of seed oils of Opuntia ficus-indica L. and Punica granatum L. from Morocco. World J Pharm Res 2015; 4(1):284-294.
54. Khémiri I, Essghaier Hédi B, Sadfi Zouaoui N, Ben Gdara N, Bitri L. The antimicrobial and wound healing potential of Opuntia ficus-indica L. inermis extracted oil from Tunisia. Evidencebased complement. Altern Med 2019; 10 pages. doi: https://dx.doi.org/10.1155/2019/9148782

55. Ennouri M, Fetoui H, Hammami M, Bourret E, Hamadi Attia NZ. Effects of diet supplementation with cactus pear seeds and oil on serum and liver lipid parameters in rats. Food Chem 2007; 101:248-253. doi: https://dx.doi.org/10.1016/j. foodchem.2006.01.026

56. Bouhrim M, Ouassou H, Choukri M, Mekhfi H, Ziyyat A, Legssyer A et al. Hepatoprotective effect of Opuntia dillenii seed oil on CCl4 induced acute liver damage in rat. Asian Pac J Trop Biomed 2018; 8(5):254-260. doi: https://dx.doi. org/10.4103/2221-1691.233006

57. Boukeloua A, Belkhiri A, Djerrou Z, Bahri L, Boulebda YHPN. acute toxicity of Opuntia ficus indica and Pistacia lentiscus seed oils in mice. Afric Networks Ethnomed 2012; 9(4):607-611.

58. Kharchoufa L, Merrouni IA, Yamani A, Elachouri M. Profile on medicinal plants used by the people of North Eastern Morocco: Toxicity concerns. Toxicon 2018; 154(September):90-113. doi: https://dx.doi.org/10.1016/j.toxicon.2018.09.003

59. Bouhrim M, Boutahiri S, Kharchoufa L, Mechchate H, Al Kamaly OM, Berraaouan A et al. Acute and subacute toxicity and cytotoxicity of Opuntia dillenii (Ker-Gawl) Haw. seed oil and its impact on the isolated rat diaphragm glucose absorption. Molecules 2021; 26(8):2172. doi: https://dx.doi.org/10.3390/molecules 26082172 